\title{
ANALISIS SISTEM KEMITRAAN PETANI PENANGKAR DAN PT. PERTANI DENGAN PT. CITRA NUSANTARA MANDIRI
}

\author{
Melani Anisa Fitri ${ }^{1}$, Roni Afrizal ${ }^{2}$, Yuliandri $^{2}$ \\ ${ }^{1}$ Mahasiswa Politeknik Pertanian Negeri Payakumbuh \\ ${ }^{2}$ Dosen Politeknik Pertanian Negeri Payakumbuh \\ Email: ronoroso@gmail.com
}

\begin{abstract}
The existence of PT. CNM Solok becomes very important as one of the guarantor of the availability of Indonesian corn seeds in order to keep corn production in a sustainable manner. In operation PT. CNM Solok in cooperation with PT. Pertani and farmer breeder. During the partnership there were two barriers: the delay in product distribution and the late payment of the contract. The purpose of this research is (1) Analyzing the partnership pattern applied by PT. CNM Solok with farmer breeders and PT. Pertani, (2) Analyze the evaluation of partnership implementation implemented by PT. CNM Solok with farmer breeders and PT. Pertani, (3) Compare the income level of the breeder farmer with regional income standard when partnering with PT. CNM Solok, (4) Describe the level of satisfaction of both partners of PT. CNM Solok is farmer breeders and PT. Pertani to the way the partnership so far. This research was carried out for 2 months from the date of February 20, until May 192018 at PT. Citra Nusantara Mandiri Solok, Solok City, West Sumatra. The study used primary data (interviews and contract documents of partnership) and secondary data were processed descriptively qualitative. Partnership pattern of PT. CNM Solok with farmer breeder ie plasma core. While the partnership pattern of PT. CNM Solok with PT. Pertani is subcontracted. The implementation of the partnership has not been fully realized. Farmers' income is lower than UMP with a land area of 0.25 hectares. Partners have been satisfied with existing partnerships.
\end{abstract}

Keywords: corn, partnership, interview, plasma core, subcontracted

\section{PENDAHULUAN}

Jumlah produksi jagung Indonesia mencapai 19,03 juta ton pada tahun 2014, membuat Indonesia masih mengimpor jagung dengan volume mencapai 3,2 juta ton (Badan Pengkajian dan Pengembangan Kebijakan Perdagangan, 2015). Pengurangan volume impor dapat dilakukan dengan melakukan peningkatan produksi jagung Indonesia secara berkelanjutan. Upaya peningkatan produksi jagung menurut Pedoman Pelaksanaan Kegiatan 2017 tentang jagung yang dikeluarkan oleh Direktorat Jenderal Tanaman Pangan Kementerian Pertanian (2016), diantaranya penggunaan varietas unggul bermutu dan menjalin kemitraan dengan stakeholders untuk penguatan modal, bantuan sarana produksi, penanganan pasca panen, dan pemasaran hasil.

PT. Citra Nusantara Mandiri Solok (PT. CNM Solok) merupakan salah satu produsen benih jagung hibrida yang berada di Kota Solok, Sumatera Barat. Keberadaan PT. CNM Solok menjadi sangat penting sebagai salah satu penjamin ketersediaan benih jagung Indonesia demi menjaga produksi jagung secara berkelanjutan. Hal ini berkaitan dengan upaya peningkatan produksi jagung. Menurut Pedoman Pelaksanaan Kegiatan 2017 sesuai uraian sebelumnya. Dalam operasionalnya PT. CNM Solok bekerjasama dengan PT. Pertani (Persero) dan petani penangkar. Kerjasama antara PT. CNM Solok dengan petani penangkar dalam hal penyediaan calon benih jagung hibrida, sedangkan kerjasama antara PT. CNM Solok dengan PT. Pertani dalam hal penjualan benih jagung hibrida.

Kerjasama atau kemitraan merupakan suatu konsep agribisnis yang dimaknai sebagai kerja sama dalam keterkaitan usaha, baik langsung maupun tidak langsung atas dasar prinsip saling memerlukan, mempercayai, memperkuat dan menguntungkan yang melibatkan pelaku usaha mikro, kecil, dan menengah dengan usaha besar (Peraturan Pemerintah Nomor 17 Tahun 2013 tentang Pelaksanaan UU No 20 Tahun 2008, Pasal 1, Butir 4). Selama kerjasama berlangsung terdapat dua hambatan yaitu keterlambatan penyaluran produk dan keterlambatan pembayaran kontrak. Keterlambatan pembayaran kontrak berasal dari pihak PT. Pertani. Sedangkan keterlambatan penyaluran disebabkan oleh ketersediaan produk di PT. CNM Solok yang belum mampu memenuhi 
permintaan PT. Pertani. Hal ini berkaitan erat dengan pelaksanaan kemitraan antara PT. CNM Solok dengan petani penangkar. Selama ini petani merupakan pihak yang dianggap lemah dan perusahaan dianggap kuat, sehingga kedudukan bermitra berlangsung tidak seimbang.

Permasalahan-permasalahan tentang sistem kemitraan di atas menjadikan penelitian tentang "Analisis Sistem Kemitraan Petani Penangkar dan PT. Pertani dengan PT. Citra Nusantara Mandiri Solok" menjadi perlu dan relevan dilakukan untuk melihat bagaimana pola sistem kemitraan yang terjadi. Tujuan penelitian yaitu menganalisis pola kemitraan yang diterapkan oleh PT. CNM Solok dengan petani penangkar dan PT. Pertani, menganalisis evaluasi pelaksanaan kemitraan yang diterapkan oleh PT. CNM Solok dengan petani penangkar dan PT. Pertani, membandingkan tingkat pendapatan petani penangkar ketika bermitra dengan PT. CNM Solok jika dibandingkan dengan standar pendapatan regional dan budidaya jagung pipil secara konvensional, dan mendeskripsikan tingkat kepuasan kedua mitra dari PT. CNM Solok yaitu petani penangkar dan PT. Pertani terhadap jalannya kemitraan selama ini.

\section{METODE PENELITIAN}

Penelitian dilakukan bersamaan dengan kegiatan Pengalaman Kerja Praktek Mahasiswa (PKPM) selama 2 bulan yang dimulai pada tanggal 20 Februari sampai 19 April 2018 di PT. CNM Solok Jl. Sapta Marga No. 001, Kelurahan Tanjung Harapan, Kecamatan Kampung Jawa, Kota Solok, Provinsi Sumatera Barat. Tahapan pelaksanaan penelitian yaitu diskusi dengan pihak perusahaan mengenai kemungkinan pengumpulan data yang dibutuhkan dan diperbolehkan, membuat janji dengan responden (petani penangkar, manajer lapangan, quality control, serta komisaris PT. CNM Solok), wawancara, transkrip wawancara, analisis data, pembuatan tugas akhir.

Jenis data yang digunakan dalam penelitian ini adalah data primer (berupa wawancara dengan responden serta dokumen kontrak kerjasama kemitraan PT. CNM Solok dengan petani penangkar) dan data sekunder (berupa data-data perusahaan PT. CNM Solok yang terkait dengan judul tugas akhir, bahan kuliah, skripsi, literatur dari buku, internet, dan lain-lain). Analisis data digunakan dengan pendekatan deskriptif kualitatif. Pengambilan data dengan wawancara dilakukan pada petani penangkar, manajer lapangan PT. CNM Solok, quality control, serta komisaris PT. CNM Solok. Analisis data yang dilakukan deskriptif kualitatif dengan cara mentranskrip wawancara setiap responden, kemudian dilakukan coding data yang dibutuhkan dan terkait untuk di bahas di pembahasan tugas akhir.

\section{HASIL DAN PEMBAHASAN}

\section{Pola Kemitraan PT. Citra Nusantara Mandiri Solok \\ Pola Kemitraan PT. Citra Nusantara Mandiri Solok dengan Petani Penangkar}

PT. CNM Solok dalam tahapan penangkaran benih jagung melakukan kemitraan dengan petani penangkar yang tersebar di lima daerah di Provinsi Sumatera Barat. Yaitu di Payakumbuh Lima Puluh Kota, Kota Solok, Kabupaten Solok, Solok Selatan, dan Dharmasraya. Alasan perusahaan melakukan kemitraan ini yaitu perusahaan tidak memiliki lahan sendiri untuk penangkaran dan untuk mewujudkan misi perusahaan dalam hal pemberian benih induk bermutu tinggi kepada petani secara gratis; penyediaan sarana produksi, memberikan pinjaman sarana produksi, dan mampu meningkatkan produktifitas dan efisiensi produksi pertanian; serta melakukan pendampingan kepada petani sehingga mampu menghasilkan produk-produk berkualitas dan diterima dengan baik oleh konsumen.

Kemitraan antara perusahaan dengan petani penangkar dilaksanakan dengan sistem perusahaan sebagai penyedia sarana prasarana produksi dan bimbingan teknis. Sedangkan petani penangkar melakukan kegiatan budidaya sesuai dengan instruksi dan kebutuhan perusahaan. Kondisi di atas sesuai dengan pola kemitraan yang telah ditetapkan perusahaan dengan petani penangkar yaitu pola kemitraan inti plasma. Sumardjo, Sulaksana, da Darmono, (2004), pola kemitraan inti plasma merupakan hubungan antara petani, kelompok tani, atau kelompok mitra sebagai plasma dengan perusahaan inti. Perusahaan inti menyediakan lahan, sarana produksi, bimbingan teknis, manajemen, menampung dan mengolah, serta memasarkan hasil produksi. Sedangkan kelompok mitra bertugas memenuhi kebutuhan perusahaan inti sesuai dengan persyaratan yang telah disepakati. Dalam penelitian ini PT. CNM Solok sebagai inti dan petani penangkar sebagai plasma. 
Keuntungan pola kemitraan bagi PT. CNM Solok sebagai pihak inti dan petani penangkar sebagai pihak plasma diidentifikasi dari tujuan kemitraan, seperti yang ada dalam Tabel 1.

Tabel 1. Identifikasi keuntungan pihak inti dan pihak plasma berdasarkan tujuan kemitraan

\begin{tabular}{|c|c|c|}
\hline \multirow{2}{*}{ Tujuan Kemitraan } & \multicolumn{2}{|c|}{ Keuntungan } \\
\hline & Pihak Inti & Pihak Plasma \\
\hline Aspek Ekonomi & $\begin{array}{l}\text { - Tersedianya bahan untuk produksi } \\
\text { dan peningkatan laba usaha. } \\
\text { - Karena lahan produksi disediakan } \\
\text { plasma, sehingga perusahaan tidak } \\
\text { perlu mengeluarkan sewa untuk lahan } \\
\text { budidaya }\end{array}$ & $\begin{array}{l}\text { - Peningkatan pendapatan. } \\
\text { - Lahan petani relatif banyak namun } \\
\text { tersebar sehingga meningkatkan } \\
\text { produktivitas lahan }\end{array}$ \\
\hline $\begin{array}{l}\text { Aspek Sosial dan } \\
\text { Budaya }\end{array}$ & $\begin{array}{l}\text { Pemenuhan tanggung jawab sosial } \\
\text { perusahaan berupa pembimbingan dan } \\
\text { pembinaan kepada petani. }\end{array}$ & $\begin{array}{l}\text { - Adanya pembinaan dan bimbingan } \\
\text { membuat petani dapat tumbuh dan } \\
\text { berkembang menjadi lebih tangguh } \\
\text { dan mandiri. } \\
\text { - Produksi relatif kontinyu sehingga } \\
\text { menyerap tenaga kerja sehingga } \\
\text { mengurangi pengangguran }\end{array}$ \\
\hline Aspek Teknologi & $\begin{array}{l}\text { - Peningkatan produktivitas dan } \\
\text { efisiensi. } \\
\text { - Memiliki modal sehingga punya akses } \\
\text { tinggi ke teknologi }\end{array}$ & $\begin{array}{l}\text { - Petani membutuhkan teknologi } \\
\text { terkini namun tidak mampu } \\
\text { membiayai informasi tersebut, } \\
\text { dengan bermitra petani bisa } \\
\text { mendapatkan hal tersebut secara } \\
\text { gratis. }\end{array}$ \\
\hline Aspek Manajemen & $\begin{array}{l}\text { Peningkatan produktivitas perusahaan } \\
\text { dalam pekerjaan. }\end{array}$ & $\begin{array}{l}\text { - Peningkatan produktivitas petani } \\
\text { dalam melaksanakan kerja. } \\
\text { - Peningkatan kesejahteraan petani }\end{array}$ \\
\hline
\end{tabular}

Tabel 1 di atas menggambarkan bahwa, masing-masing pihak memiliki keuntungan dari kerjasama yang telah dilakukan. Hal ini berpengaruh baik terhadap konsistensi pihak inti dan pihak plasma dalam menjalankan kemitraan agar keuntungan yang telah ada saat ini dapat ditingkatkan dan dioptimalkan sebaik mungkin. Sehingga kegiatan kemitraan bisa berlangsung dalam jangka waktu yang lebih lama.

\section{Pola Kemitraan PT. Citra Nusantara Mandiri Solok dengan PT. Pertani}

Sistem awal kerjasama PT. CNM Solok dengan PT. Pertani bersifat negosiasi. Sesuai dengan salah satu prinsip kemitraan (Ditjen P2L \& PM, 2016), yaitu prinsip keterbukaan yang mencakup hal-hal terkait kekurangan atau kelemahan masing-masing anggota serta berbagai sumber daya yang dimiliki. Semua itu harus diketahui oleh semua anggota mitra. Maka dari itu, sistem negosiasi ini penting untuk dilakukan.

Sistem kerjasama bersifat pemenuhan permintaan PT. Pertani oleh PT. CNM Solok. Dimana produksi dari PT. CNM Solok didistribusikan ke gudang-gudang PT. Pertani yang ada di setiap provinsi di Indonesia yang kemudian dipasarkan oleh PT. Pertani ke petani-petani seluruh Indonesia. PT. CNM Solok memiliki kewajiban untuk menjamin produksi benih jagung hibrida mencakup mutu dan volume benih jagung hibrida yang dibutuhkan oleh PT. Pertani. Produk yang dihasilkan oleh PT. CNM Solok dikemas dengan dus dan kemasan yang berasal dari PT. Pertani. Pada kemasan benih jagung hibrida memuat kata-kata bahwa benih jagung hibrida diproduksi oleh PT. Pertani dengan dukungan teknologi dari PT. CNM Solok Sumbar. Berdasarkan hal tersebut dapat dilihat bahwa terjadi alih teknologi oleh PT. CNM Solok dan yang memasarkannya adalah PT. Pertani. Berdasarkan sistem kerjasama di atas maka pola kemitraan antara PT. CNM Solok dengan PT. Pertani adalah pola kemitraan subkontrak. Sumardjo dkk, (2004), menuturkan bahwa pola kemitraan subkontrak adalah pola kemitraan antara perusahaan mitra dengan kelompok mitra yang memproduksi komponen yang diperlukan perusahaan mitra sebagai bagian dari produksinya Pada kondisi kemitraan PT. CNM Solok, PT. CNM Solok merupakan pihak kelompok mitra dan PT. Pertani merupakan perusahaan mitranya. Selain itu pada pola kemitraan subkontrak juga tercipta alih teknologi, modal, keterampilan, produktivitas, serta terjaminnya pemasaran produk pada PT. CNM Solok. 


\section{Evaluasi Pelaksanaan Kemitraan PT. Citra Nusantara Mandiri Solok dengan Petani Penangkar \\ Evaluasi Pelaksanaan Kemitraan PT. CNM Solok dengan Petani Penangkar}

Kemitraan antara PT. CNM Solok dengan petani penangkar telah memiliki kontrak kerjasama yang dituangkan dalam beberapa dokumen, antara lain: (1) Syarat-syarat menjadi penangkar benih jagung hibrida; (2) Syarat-syarat lahan yang akan dijadikan penangkaran jagung hibrida; (3) Surat permohonan menjadi petani penangkar; (4) Panduan pra tanam dan tanam; dan (5) Sistem Kerjasama (mencakup kewajiban inti, kewajiban plasma, dan sistem pemrosesan). Kelima dokumen tentang petunjuk kemitraan ini telah tertuang secara tertulis.

Berdasarkan kutipan wawancara responden A dan E diketahui bahwa petani penangkar melakukan kemitraan tanpa adanya penandatanganan kontrak. Namun perusahaan memberikan informasi petunjuk budidaya dan aturan kerjasama dalam bentuk selebaran. Kondisi ini juga ditemui pada sistem kemitraan yang diterapkan oleh PT. Lumbung Padi dengan petani di Kabupaten Garut sesuai dengan hasil penelitian Cahyanto (2015), yang menemukan bahwa semua mitra tani tidak memiliki surat perjanjian tertulis sebagaimana yang telah ditetapkan pada syarat bermitra. Hal ini terjadi karena rasa saling percaya dan kekeluargaan yang sangat tinggi sehingga dikhawatirkan timbul rasa curiga dan rasa ketidakpercayaan apabila salah satu pihak bertanya mengenai surat perjanjian kemitraan. Penuturan berbeda disampaikan oleh responden B bahwa pada awal melakukan kerjasama, terdapat kontrak kerjasama yang diberikan secara tertulis kepada petani penangkar oleh PT. CNM Solok. Menurut Rahman (2008), di dalam kontrak perjanjian terkandung aspek-aspek perjanjian yang harus disepakati bersama oleh ke dua belah pihak. Sehingga adanya penandatangan kontrak tertulis antara PT. CNM Solok dengan petani penangkar memberikan jaminan hukum yang kuat untuk petani penangkar sebagai plasma dan perusahaan sebagai inti.

Kontrak kerjasama dalam hal syarat-syarat menjadi petani penangkar benih jagung hibrida, dari 19 point kesepakatan belum semuanya terealisasi. Beberapa kesepakatan yang belum terealisasi diantaranya: (1) Luas lahan yang akan ditanami minimal $5 \mathrm{Ha} /$ lokasi; (2) Biaya transportasi dan karung untuk panen, tanggung jawab PT. CNM Solok; (3) Harga panen dalam bentuk tongkol tanpa kulit adalah Rp. 2.300,-/kg (apabila dinyatakan lulus sebagai benih oleh Balai Pengawasan dan Sertifikasi Benih Sumatera Barat), Rp. 8.00,-/kg (apabila dinyatakan tidak lulus sebagai benih oleh Balai Pengawasan dan Sertifikasi Benih Sumatera Barat); (4) Pembayaran panen dilakukan 7 hari kerja setelah hasil panen diterima pada bagian processing. Point-point kesepakatan yang tidak terealisasi ini akan berdampak pada empat sisi, yaitu: (a) Produksi calon benih jagung hibrida, (b) Petani penangkar, (c) PT. CNM Solok, (d) Kontrak di masa yang akan datang

Berdasarkan kutipan wawancara diketahui bahwa kerjasama yang dilakukan PT. CNM Solok dengan petani penangkar tidak bersifat terikat. Dalam artian kontrak tetap akan berlanjut selama petani mau melakukan kemitraan. Apabila petani merasa diuntungkan dengan adanya kemitraan, maka kemitraan tetap akan dilanjutkan. Berdasarkan kutipan wawancara dari responden B diketahui bahwa petani merasa diuntungkan dengan adanya kemitraan dan telah mampu memenuhi kebutuhan hidup untuk keluarga sehingga kemitraan tetap dilanjutkan. Selain itu responden juga akan melanjutkan mitra selama perusahaan tetap memberikan benih kepada mereka. Apabila ada petani penangkar yang tidak melanjutkan kemitraan, maka perusahaan akan mencari petani penangkar lain yang mau melakukan kemitraan untuk menstabilkan pasokan calon benih jagung hibrida, perusahaan melakukan penambahan petani ke wilayah lainnya yang dilakukan oleh petugas lapangan yang telah ditunjuk oleh perusahaan. Sehingga perusahaan tetap mampu mengontrol proses produki dalam hal penyediaan bahan baku calon benih jagung hibrida.

Pelaksanaan kemitraan kemitraan juga dapat dilihat dari syarat-syarat lahan yang akan dijadikan penangkaran benih jagung hibrida. Pelaksanaan kemitraan ini diketahui dari 9 point yang ada, hanya satu responden yang memenuhi syarat lahan tersebut. Sedangkan ada 4 responden yang tidak memenuhi syarat lahan sebanyak 1 sampai 2 syarat. Syarat yang tidak dipenuhi petani antara lain: Petani tidak dibenarkan melakukan penyisipan pada tanaman yang tidak tumbuh dan saluran pengairan baik dan ketersediaan air mencukupi.

Sesuai dengan kontrak kerjasama PT. CNM Solok dengan petani penangkar bahwa produk yang dihasilkan petani penangkar berupa calon benih jagung hibrida yang memenuhi standar BPSB dijual seluruhnya kepada PT. CNM Solok. Sedangkan PT. CNM Solok memfasilitasi segala saprodi (sarana produksi) berupa (a) Benih induk; (2) Roundup/herbisida dengan pinjaman dana tanpa bunga; dan (3) Pupuk kimia dengan pinjaman dana tanpa bunga. PT. CNM Solok dan petani penangkar 
sebagai mitra memiliki kewajiban inti dan kewajiban plasma. Kewajiban inti dan plasma pelaksanaannya selama ini sudah cukup baik. Sirajuddin, Aminawar, Rohani, Lestari, Siregar, dan Aryanto (2015), menyatakan bahwa ketika mitra melaksanakan hak dan kewajiban sesuai dengan kesepakatan kerjasama yang telah dibuat, maka hubungan usaha akan berjalan dengan baik dan berpengaruh terhadap hubungan kerjasama serta kesinambungan usaha bagi kedua belah pihak.

Hasil evaluasi pelaksanaan kemitraan antara petani penangkar dengan PT. CNM Solok menghasilkan informasi kerugian yang diterima oleh petani penangkar yang disajikan dalam tabel berikut ini.

Tabel 2. Identifikasi kerugian pelaksanaan kemitraan yang diterima oleh petani penangkar

\begin{tabular}{ll}
\hline \multicolumn{1}{c}{ Indikator } & \multicolumn{1}{c}{ Kerugian } \\
\hline Aspek ekonomi & Apabila petani penangkar hanya menggantungkan hidupnya \\
& pada kerjasama dengan PT. CNM Solok, maka pendapatan \\
& petani perbulannya belum bisa terjamin sepenuhnya karena \\
& adanya sistem bertahap pada penangkaran. \\
& - Harga tawar petani terhadap harga masih rendah sehingga \\
& harga yang diterima petani selama ini hanya berdasarkan yang \\
& disampaikan oleh perusahaan saja. \\
\hline Aspek kekuatan hukum kontrak & - \\
kerjasama ada kontrak kerjasama yang menjamin hak dan \\
kewajiban plasma secara hukum sehingga apabila terjadi \\
permasalahan, petani tidak memiliki kekuatan hukum untuk \\
menuntut hak nya kepada perusahaan. \\
\hline Aspek manajemen & Komitmen PT. CNM Solok masih lemah dalam memenuhi \\
& fungsi dan kewajibannya sesuai dengan kesepakatan yang \\
& diharapkan plasma dalam hal sosialisasi kesepakatan \\
& kerjasama kepada petani penangkar. \\
\hline
\end{tabular}

Tabel 2 menginformasikan bahwa ada beberapa kerugian yang diterima oleh petani penangkar dalam pelaksanaan kemitraan dengan PT. CNM Solok. Kerugian-kerugian tersebut sampai saat ini masih belum memiliki solusi nyata yang dilakukan oleh perusahaan. Namun, beberapa solusi perbaikan yang bisa dilakukan agar kerugian ini bisa diminimalisir yaitu: petani memiliki sumber pendapatan lain selain menjadi petani penangkar; petani secara individu maupun berkelompok mengumpulkan dan menyampaikan aspirasi atau negosiasi terhadap kebijakankebijakan atau ketetapan dalam pelaksanaan kemitraan kepada petugas lapang maupun kepada pihak manajemen perusahaan; perusahaan melakukan peninjauan terhadap kontrak kerjasama yang sudah ada dan melakukan evaluasi setiap tahunnya agar kontrak kerjasama diperbaharui dan disesuaikan setiap tahunnya dengan keadaan kemitraan yang real di lapangan; dan perusahaan menekankan kepada petugas lapang yang ditunjuk sebagai perpanjangan tangan perusahaan kepada petani penangkar untuk mensosialisasikan hak dan kewajiban perusahaan maupun petani agar petani tau dan mampu memberikan komplain apabila perusahaan belum menjalankan kewajibannya sebagai pihak inti.

\section{Evaluasi Pelaksanaan Kemitraan PT. Citra Nusantara Mandiri Solok dengan PT. Pertani}

PT. CNM Solok dengan PT. Pertani telah memiliki kontrak kerjasama yang diperbaharui setiap tahunnya. Namun karena kontrak ini berkaitan dengan pemerintah, dalam hal ini BUMN dengan PT. CNM Solok, maka untuk kontrak kerjasama tertulis tidak bisa diberikan perusahaan untuk diolah dan dibahas. Karena kontrak kerjasama ini bersifat rahasia.

Pelaksanaan kontrak kerjasama bersifat pemenuhan permintaan benih jagung hibrida dari PT. Pertani oleh PT. CNM Solok. PT. CNM Solok akan memproduksi benih jagung hibrida sesuai dengan kontrak yang ditandatangi setiap tahunnya oleh direktur. Selama tahun 2017, kontrak produksi yang harus dipenuhi oleh PT. CNM Solok akan digambarkan pada Tabel 3 berikut ini.

Tabel 3. Pengiriman benih jagung hibrida ke PT. Pertani tahun 2017

\begin{tabular}{|l|l|l|l|l|}
\hline \multirow{2}{*}{ No } & \multirow{2}{*}{ Bulan } & \multicolumn{3}{|l|}{ Jumlah Pengiriman Barang ke PT. Pertani (kg) } \\
\cline { 3 - 5 } & & JH-27 & URI-19 & Jumlah \\
\hline 1 & Januari & & & \\
\hline 2 & Februari & & & \\
\hline 3 & Maret & & & \\
\hline
\end{tabular}




\begin{tabular}{|l|l|l|l|l|}
\hline \multirow{2}{*}{ No } & \multirow{2}{*}{ Bulan } & \multicolumn{3}{|l|}{ Jumlah Pengiriman Barang ke PT. Pertani (kg) } \\
\cline { 3 - 5 } & & JH-27 & URI-19 & Jumlah \\
\hline 4 & April & & 121.405 & 121.405 \\
\hline 5 & Mei & & 87.500 & 87.500 \\
\hline 6 & Juni & & & \\
\hline 7 & Juli & 44.000 & 122.620 & 166.620 \\
\hline 8 & Agustus & & 141.180 & 141.180 \\
\hline 9 & September & 100.934 & 182.025 & 282.959 \\
\hline 10 & Oktober & 73.500 & 196.073 & 269.573 \\
\hline 11 & November & 146.657 & & 146.675 \\
\hline 12 & Desember & & 3.715 & 3.715 \\
\hline Jumlah & $\mathbf{3 6 5 . 1 0 9}$ & $\mathbf{8 5 4 . 5 1 8}$ & $\mathbf{1 . 2 1 9 . 6 2 7}$ \\
\hline
\end{tabular}

Sumber: Data sekunder PT. CNM Solok, 2017

Berdasarkan Tabel 3 di atas diketahui bahwa total pengiriman benih jagung hibrida ke PT. Pertani pada tahun 2017 sebanyak $1.219 .627 \mathrm{~kg}$ atau 1.219 ton. Total produksi tersebut masih kurang pengirimannya ke PT. Pertani sebanyak 511 ton. Dan dari pihak PT. Pertani juga terjadi keterlambatan pembayaran untuk $200 \mathrm{~kg}$ benih jagung hibrida. Namun, pada tahun 2018 keterlambatan pengiriman produk oleh PT. CNM Solok sudah dipenuhi dan begitu juga dengan PT. Pertani telah memenuhi pembayaran untuk $200 \mathrm{~kg}$ benih tersebut (Manager Administrasi dan Keuangan PT. CNM Solok, 2018).

Permasalahan di atas dapat diartikan bahwa pada pelaksanaan kemitraan memiliki dua permasalahan yang belum bisa dihindari yaitu keterlambatan pengiriman produk dari PT. CNM Solok dan keterlambatan pembayaran dari PT. Pertani. Permasalahan tersebut merupakan permasalahan terbesar yang dihadapi selama kemitraan berjalan. Sehingga pelaksanaan kemitraan antara PT. CNM Solok dengan PT. Pertani belum sepenuhnya berjalan dengan baik. Namun, hal ini tidak menjadi tembok penghalang yang besar bagi ke dua pihak, karena dari mulai bermitra pada tahun 2004 sampai sekarang pada tahun 2018 kontrak kerjasama tidak pernah terputus.

\section{Perbandingan Tingkat Pendapatan Petani Penangkar jika dibandingkan dengan Standar Pendapatan Regional ketika bermitra dengan PT. Citra Nusantara Mandiri Solok}

Tingkat pendapatan petani penangkar dapat diketahui dari luas lahan produksi dan hasil dari produksi jagung. Hal ini sesuai dengan yang disampaikan oleh Wibowo (2013), bahwa pendapatan petani berkaitan erat dengan luas lahan budidaya dan total produksi. Rata-rata luas lahan petani penangkar yang bermitra dengan PT. CNM Solok antara 0,25-3 hektar. Luas lahan yang digunakan untuk perhitungan proyeksi/perkiraan pendapatan petani penangkar yaitu 0,25 hektar. Hal ini didasarkan oleh asumsi yaitu: (1) Lebih kurang $96 \%$ dari total jumlah petani penangkar memiliki lahan <1 hektar; dan (2) Memuaskan perhitungan.

Total produksi yang bisa dihasilkan petani dalam $1 \mathrm{~kg}$ benih minimal yaitu $500 \mathrm{~kg}$. Di dalam 1 hektar lahan biasanya memerlukan minimal $10 \mathrm{~kg}$ benih. Maka produksi 1 hektar lahan lebih kurang 5 ton. Sehingga produki rata-rata untuk luasan 0,25 hektar yaitu 1,25 ton satu kali periode panen. Berdasarkan harga kontrak kemitraan, perusahaan akan menghargai $1 \mathrm{~kg}$ jagung seharga Rp2.300 / kg apabila diasumsikan semua hasil produksi dinyatakan lulus oleh BPSB. Maka dari itu, diasumsikan dengan harga tersebut dan perkiraan produksi di atas maka penerimaan petani penangkar lebih kurang Rp2.875.000. Selain penerimaan dari produksi jagung, petani penangkar juga mendapatkan ganti rugi malecutting (pemotongan tanaman jantan) sebesar Rp250.000 per hektar lahan produksi sehingga untuk luasan 0,25 hektar petani mendapat ganti rugi sebesar Rp62.500. Sehingga penerimaan total petani penangkar dapat diasumsikan sebesar Rp2.937.500 dalam 1 periode panen.

Wibowo (2013), menyebutkan bahwa pendapatan petani merupakan keuntungan bersih yang diterima oleh petani dalam proses produksi. Pendapatan ini diperoleh dari keseluruhan penerimaan dikurangi dengan keseluruhan biaya produksi. Biaya produksi yang dikeluarkan oleh petani penangkar yang bermitra dengan PT. CNM Solok antara lain sewa lahan, pinjaman pupuk dan roundup, biaya tenaga kerja (kecuali biaya tenaga kerja untuk dettaseling). Untuk lahan, beberapa 
petani memiliki lahan dengan kepemilikan sendiri yaitu responden $\mathrm{D}$ dan $\mathrm{E}$, ada juga petani yang memiliki kepemilikan lahan secara sewa pakai saja yaitu responden $C$, sedangkan beberapa petani memiliki lahan secara sewa yaitu responden A dan B. Berdasarkan wawancara responden dapat diasumsikan bahwa petani penangkar mengeluarkan sewa untuk lahannya minimal sebesar Rp100.000.

Panduan kontrak kemitraan antara PT. CNM Solok dengan petani penangkar terkait pupuk yaitu pupuk I (pupuk kompos) sebanyak $300 \mathrm{~kg} /$ hektar, pupuk II (pupuk lengkap) sebanyak $450 \mathrm{~kg}$ / hektar, dan pupuk III (pupuk urea) sebanyak $150 \mathrm{~kg} /$ hektar. Sehingga diasumsikan untuk pupuk petani mengeluarkan biaya sebesar Rp17.550 per 0,25 hektar nya. Untuk pupuk II petani mengeluarkan biaya sebesar Rp258.750 per 0,25 hektar nya. Untuk pupuk III petani mengeluarkan biaya sebesar Rp67.500 per 0,25 hektar nya. Sehingga untuk satu 0,25 hektar lahan penangkaran, petani penangkar harus mengeluarkan biaya sebesar Rp343.800.

Biaya yang harus dikeluarkan petani untuk ganti rugi penggunaan roundup yaitu sebesar Rp. 150.000 per hektar. Maka untuk luasan 0,25 hektar diperlukan biaya roundup sebesar Rp. 37.500. Sedangkan biaya tenaga kerja untuk luasan 0,25 hektar didasarkan pada kutipan wawancara responden $\mathrm{D}$, tenaga kerja tidak diupahkan sehingga diasumsikan untuk tenaga kerja pada luas lahan 0,25 hektar tidak memiliki biaya. Maka, total biaya produksi yang harus dikeluarkan petani untuk luas lahan 0,25 hektar yaitu Rp481.300.

Penerimaan rata-rata yang diasumsikan sebesar Rp. 2.937 .500 per 0,25 hektar dalam 1 periode panen, apabila dikurangkan dengan asumsi total biaya produksi sebesar Rp481.300. Maka pendapatan petani penangkar untuk luasan 0,25 hektar lebih kurang sebesar Rp2.456.200 per periode tanam. 1 kali periode tanam selama lebih kurang 100 hari (lebih kurang 3 bulan). Maka pendapatan petani penangkar per bulannya untuk luas lahan 0,25 hektar diasumsikan lebih kurang Rp818.733.

Upah Minimum Provinsi (UMP) Sumatera Barat tahun 2018 berdasarkan Keputusan Gubernur Sumatera Barat Nomor 562-879-2017 sebesar Rp2.119.067 per bulan. Apabila dibandingkan dengan tingkat pendapatan petani penangkar per bulannya dengan luas lahan 0,25 hektar yaitu Rp818.733, maka pendapatan petani tersebut masih berada di bawah UMP. Agar mencapai standar UMP Sumatera Barat, petani penangkar harus memiliki lahan lebih kurang 0,65 hektar.

Pendapatan petani penangkar apabila dibandingkan dengan pendapatan petani konvensional jagung pipil disajikan dalam Tabel 4 berikut.

Tabel 4. Perbandingan pendapatan petani penangkar dengan petani konvensional jagung pipil.

\begin{tabular}{|c|c|c|c|c|c|c|}
\hline No & Nama & $\begin{array}{l}\text { Luas Lahan } \\
\text { (1) }\end{array}$ & $\begin{array}{c}\text { Pendapatan } \\
\text { untuk luas } \\
\text { lahan (1) }\end{array}$ & $\begin{array}{c}\text { Umur } \\
\text { Tanaman }\end{array}$ & $\begin{array}{c}\text { Pendapatan } \\
\text { untuk luas lahan } \\
0,25 \\
\text { hektar/periode } \\
\text { tanam }\end{array}$ & $\begin{array}{c}\text { Pendapatan } \\
\text { untuk luas } \\
\text { lahan } 0,25 \\
\text { hektar/bulan }\end{array}$ \\
\hline 1 & $\begin{array}{l}\text { Petani } \\
\text { penangkar }\end{array}$ & 0,25 hektar & Rp2.456.200 & 3 bulan & Rp2.456.200 & Rp818.733 \\
\hline 2 & $\begin{array}{l}\text { *Petani } 1 \\
\text { (Konvensional } \\
\text { jagung pipil) }\end{array}$ & 0,0125 hektar & Rp49.685 & 4 bulan & Rp993.700 (1) & Rp248.425 (3) \\
\hline 3 & $\begin{array}{l}\text { **Petani } 2 \\
\text { (Konvensional } \\
\text { jagung pipil) }\end{array}$ & 0,0125 hektar & Rp82.916 & 4 bulan & Rp1.658.320 (2) & Rp414.580 \\
\hline
\end{tabular}

Keterangan:

* Data Petani 1, (Ananda, 2018)

** Data Petani 2, (Abdurrahman, 2018)

(1), (2), (3), dan (4) merupakan hasil konversi

Berdasarkan tabel di atas, diketahui bahwa pendapatan petani penangkar yang melakukan penangkaran benih jagung dari PT. CNM Solok memiliki pendapatan per bulan lebih tinggi dibandingkan dengan petani 1 dan petani 2 . Dimana pendapatan petani penangkar sebesar Rp818.733/bulan, sedangkan petani 1 Rp248.425/bulan dan petani 2 Rp414.580/bulan. Hal ini dapat disimpulkan bahwa dilihat dari segi pendapatan, petani bisa mendapatkan pendapatan lebih tinggi per bulannya apabila melakukan kemitraan dengan PT. CNM Solok. 


\section{Tingkat Kepuasan Mitra terhadap PT. Citra Nusantara Mandiri Solok}

Kepuasan merupakan kondisi dimana ekspektasi sesuai atau lebih dari kenyataan di lapangan. Kepuasan petani penangkar dan PT. Pertani terhadap PT. CNM Solok dinilai penting bagi kelangsungan produksi PT. CNM Solok karena kepuasan petani penangkar dan PT. Pertani terhadap kemitraan mampu menentukan keberlanjutan kemitraan di masa yang akan datang. Analisis tingkat kepuasan mitra terhadap PT. CNM Solok dapat ditinjau salah satunya dari pendekatan prinsip kemitraan. Berdasarkan prinsip-prinsip kemitraan yang disampaikan oleh Ditjen P2L \& PM (2004), yaitu prinsip kesetaraan (Equity), keterbukaan, dan azas manfaat bersama. Maka, dapat diuraikan sebagai berikut:

1. Prinsip Kesetaraan (Equity)

Berdasarkan prinsip ini, petani penangkar dan PT. Pertani memiliki kedudukan yang berbeda dalam kegiatan kemitraan dengan PT. CNM Solok. Meskipun kedudukan petani mitra, PT. Pertani, dan PT. CNM Solok memiliki perbedaan, namun hal ini tidak melanggar adanya prinsip kesetaraan (Equity). Karena masing-masing pihak telah melaksanakan tanggungjawab masing-masing sesuai dengan kedudukannya.

\section{Prinsip Keterbukaan}

Berdasarkan makna dari prinsip ini, petani penangkar dan PT. Pertani sebagai mitra dari PT. CNM Solok telah mengetahui hal-hal terkait kekurangan dan kelemahan masing-masing, sehingga menimbulkan saling melengkapi dan saling membatu diantara mitra. Hal ini terwujud dari bimbingan teknis yang dilakukan perusahaan terhadap petani penangkar karena perusahaan mengetahui bahwa petani penangkar belum memiliki keterampilan dalam berbudidaya benih jagung induk yang dikhususkan untuk calon benih jagung hibrida. Dengan PT. Pertani terjadi dua hambatan, dari segi PT. Pertani yaitu adanya keterlambatan pembayaran produk. Sedangkan dari segi PT. CNM Solok adanya keterlambatan penyaluran produksi. Dengan diketahuinya kekurangan masing-masing ini, maka bisa ditemukan solusi apa yang bisa dilakukan. Seperti yang disampaikan oleh Windarsari (2007), bahwa setiap pelaku usaha memiliki kemampuan dan keistimewaan masing-masing. Dari pelaku usaha yang mempunyai kelebihan dan kekurangan diharapkan mampu untuk saling menutupi kekurangan masing-masing sehingga timbul kebutuhan untuk bekerjasama dan menjalin kemitraan.

\section{Prinsip Azas Manfaat Bersama}

Berdasarkan makna dari prinsip ini, kemitraan antara petani penangkar dan PT. Pertani dengan PT. CNM Solok telah menjalin kemitraan dengan memperoleh manfaat sesuai kontribusi masingmasing. Sehingga kegiatan akan berjalan secara efektif dan efisien. Sirajuddin, Aminawar, Rohani, Lestari, Siregar, dan Aryanto (2015), menyebutkan bahwa prinsip azas manfaat bersama dapat tercermin dari kemampuan kedua belah pihak untuk saling memperkuat kedudukan masing-masing mitra dalam meningkatkan daya saing usaha.

Analisis tingkat kepuasan kemitraan antara PT. CNM Solok dengan petani penangkar juga dapat dilihat dari pendekatan alasan petani penangkar melakukan kemitraan dan masih mau melanjutkan kemitraan di masa yang akan datang. Adapun alasan petani penangkar melakukan kemitraan menurut masing-masing responden. Berdasarkan penuturan responden, diketahui bahwa petani penangkar merasa puas dengan kemitraan yang dilakukan bersama PT. CNM Solok terkait pemasaran jagung yang sudah pasti dibeli oleh perusahaan, adanya kepastian harga sehingga petani tidak takut apabila harga di pasaran berubah, adanya pemberian modal berupa pinjaman tanpa bunga, adanya sistem hangus biaya sehingga tidak menimbulkan hutang, serta pelaksanaan budidaya calon benih jagung hibrida lebih mudah daripada berbudidaya padi.

Alasan-alasan di atas bermakna bahwa petani merasa puas, aman, dan tidak mengkhawatirkan resiko dalam pelaksanaan kemitraan. Sehingga keberlangsungan kemitraan di masa yang akan datang dapat terus berjalan. Hafsah (2005), menyatakan bahwa kemitraan bermanfaat untuk mengurangi resiko yang dihadapi kedua belah pihak yang bermitra. Yudhabaskara (2017), menambahkan bahwa apabila pelayanan perusahaan inti dirasa plasma/petani tidak memberikan manfaat mengurangi risiko yang mereka hadapi maka akan berpengaruh langsung pada kepuasan peternak terhadap pelayanan perusahaan inti. 


\section{KESIMPULAN}

Kesimpulan dari penelitian tentang "Analisis Sistem Kemitraan Petani Penangkar dan PT. Pertani dengan PT. Citra Nusantara Mandiri Solok", yaitu:

1. Pola kemitraan antara PT. CNM Solok dengan petani penangkar yaitu pola inti plasma. PT. CNM Solok sebagai inti berperan menyediakan saprodi dan bimbingan teknis. Sedangkan petani penangkar sebagai plasma berperan untuk melakukan kegiatan budidaya sesuai dengan instruksi dan kebutuhan perusahaan.

2. Pola kemitraan antara PT. CNM Solok dengan PT. Pertani yaitu pola subkontrak. PT. CNM Solok berperan menyediakan produksi dengan menjamin mutu dan volume produk. Sedangkan PT. Pertani berperan memasarkan produk dari PT. CNM Solok.

3. Evaluasi pelaksanaan kemitraan antara PT. CNM Solok dengan petani penangkar berdasarkan kontrak kerjasama terdapat point yang belum terealisasi, yaitu luas lahan minimal 5 hektar, biaya karung dan penangkutan menjadi tanggung jawab PT. CNM Solok, harga panen tongkol, pembayaran 7 hari kerja setelah panen, petani tidak dibenarkan melakukan penyisipan pada tanaman yang tida tumbuh, dan saluran pengairan baik dan ketersediaan air mencukupi.

4. Evaluasi pelaksanaan kemitraan antara PT. CNM Solok dengan PT. Pertani yaitu belum sepenuhnya berjalan dengan baik karena ada dua hambatan yaitu keterlambatan penyaluran produksi dan keterlambatan pembayaran produk.

5. Tingkat pendapatan petani yang bermitra dengan PT. CNM Solok dengan luas lahan terendah 0,25 hektar masih rendah dari UMP Sumatera Barat 2018. Agar pendapatan petani melebihi UMP Sumatera Barat, maka petani harus memiliki lahan garapan lebih kurang 0,65 hektar. Dibandingkan dengan pendapatan petani yang berbudidaya jagung pipil secara konvensional, petani penangkar bisa mendapatkan pendapatan lebih tinggi per bulannya apabila melakukan kemitraan dengan PT. CNM Solok. Dibandingkan dengan petani 1, petani penangkar bisa mendapatkan 69,66\% pendapatan lebih tinggi per bulannya ketika bermitra dengan PT. CNM Solok. Sedangkan dibandingkan dengan petani 2, petani mitra bisa mendapatkan 49,36\% pendapatan lebih tinggi per bulannya ketika bermitra dengan PT. CNM Solok.

6. Tingkat kepuasan petani penangkar dan PT. Pertani terhadap kemitraan dengan PT. CNM Solok telah cukup baik dimana pelaksanaan kemitraan tidak bertentangan dengan pendekatan prinsip kesetaraan, keterbukaan, dan azas manfaat bersama. Berdasarkan pendekatan alasan petani bermitra, petani merasa puas terkait pemasaran jagung yang sudah dipasti dibeli oleh perusahaan, adanya kepastian harga sehingga petani tidak takut apabila harga di pasaran berubah, adanya pemberian modal berupa pinjaman tanpa bunga, adanya sistem hangus biaya sehingga tidak menimbulkan hutang, serta pelaksanaan budidaya calon benih jagung hibrida lebih mudah daripada berbudidaya padi.

\section{DAFTAR PUSTAKA}

Badan Pengkajian dan Pengembangan Kebijakan Perdagangan. 2015. Potret Jagung Indonesia: Menuju Swasembada Tahun 2017. Kementerian Perdagangan Republik Indonesia.

Cahyanto, C. 2015. Pola Kemitraan Usahatani Kedelai Edamame (Glycine max (L) Merr) antara Petani dengan PT. Lumbung Padi di Kabupaten Garut. Skripsi. Program Studi Agribisnis Fakultas Pertanian Universitas Muhammadiyah Yogyakarta. Yogyakarta.

Direktorat Jenderal Tanaman Pangan Kementerian Pertanian. 2016. Pedoman Pelaksanaan Kegiatan 2017 Jagung. Jakarta.

Ditjen P2L \& PM. 2004. Pelatihan Manajemen P2L \& PL Terpadu Berbasis Wilayah Kabupaten/Kota Membina Kemitraan Berbasis Institusi. Depkes RI.

Gubernur Sumatera Barat. 2017. Keputusan Gubernur Sumatera Barat Nomor 562-879-2017 tentang Upah Minimum Provinsi Sumatera Barat Tahun 2018. https://www.google.co.id/url?sa=t\&rct=j\&q=\&esrc=s\&source=web $\& c d=2 \& c a d=r j a \& u a c t=8 \& v e d=0$ ahUKEwiEve_uioPbAhVHqI8KHQ81CE4QFggyMAE\&url $=$ https $\% 3 \mathrm{~A} \% 2 \mathrm{~F} \% 2 \mathrm{Fwww}$. sumbarprov.go.id $\% 2$ Fimages $\% 2 \mathrm{~F} 2017 \% 2 \mathrm{~F} 11 \% 2 \mathrm{Ffile} \% 2 \mathrm{FUMP}$ 2018.pdf\&usg=AOvVaw0-YLTSbivf_mYPPOvsecNG. Diakses pada 13 Mei 2018.

Hafsah, M. J. 2005. Kemitraan Usaha: Konsepsi dan Strategi. Pustaka Sinar Harapan. Jakarta. 
Peraturan Pemerintah Nomor 17 Tahun 2013 tentang Pelaksanaan UU No 20 Tahun 2008. http://www.hukumonline.com/pusatdata/detail/lt5149b4db pemerintah-nomor-17-tahun-2013. Diakses pada 20 April 2018.

Rahman, C. A. Y. 2008. Evaluasi Kemitraan Pemuda Tani Indonesia dan Pengaruhnya terhadap Pendapatan Usahatani (Studi Kasus di Kelurahan Sukatani Kecamatan Cimanggis Depok, Jawa Barat). Institut Pertanian Bogor. Jawa Barat

Sirajjudin, S. N., M. Aminawar, St. Rohani, V. S. Lestari, A. R. Siregar, dan T. Aryanto. 2015. Analisis Kontrak Sistem Kemitraan Ayam Ras Pedaging dan Kaitannya dengan UndangUndang Nomor 5 Tahun 1999 tentang Larangan Praktek Monopoli dan Persaingan Usaha Tidak Sehat. JITP 4(2): 79-84.

Sumardjo, Sulaksana J, dan Darmono WA. 2004. Kemitraan Agribisnis. Penebar Swadaya. Jakarta. Wibowo, E. 2013. Pola Kemitraan antara Petani Tebu Rakyat Kredit (TRK) dan Mandiri (TRM) dengan Pabrik Gula Modjopanggoong Tulungagung. Jurnal Manajemen Agribisnis 13(1): 112.

Windarsari. 2007. Kajian Usaha Peternakan Ayam Ras Pedaging di Kabupaten Karanganyar: Membandingkan antara Pola Kemitraan dan Pola Mandiri. Tesis. Sekolah Pascasarjana Institut Pertanian Bogor. Bogor.

Zaelani, A. 2008. Manfaat kemitraan agribisnis bagi petani mitra (Kasus : Kemitraan PT. Pupuk Kujang dengan kelompok tani Sri Mandiri Desa Majalaya Kecamatan Majalaya Kabupaten Karawang, Provinsi Jawa Barat). Institut Pertanian Bogor. Jawa Barat. 